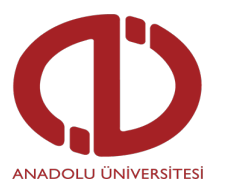

Açıköğretim Uygulamaları ve Araştırmaları Dergisi

AUAd

https://dergipark.org.tr/tr/pub/auad

Gönderim: 19.08 .2021

Düzeltme: 12.10 .2021

Kabul: 25.10 .2021

Tür: Araştırma Makalesi

\title{
Öğretmen adaylarının derslerde bir eğitsel sosyal ağ kullanımına ilişkin görüşleri ${ }^{1}$
}

\author{
Çisem YAŞAR ${ }^{\mathrm{a}}$ \\ Gülcan ÖZTÜRK ${ }^{\mathrm{b}}$
}

a İstanbul Gelişim Üniversitesi, İstanbul Gelişim Meslek Yüksekokulu, Bilgisayar Teknolojisi Programı, ORCID: 0000-00020765-861X

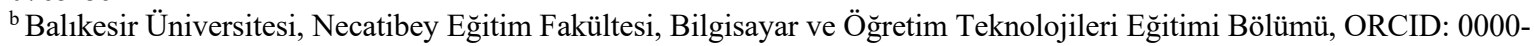
0003-4399-1329

\begin{abstract}
Özet
Bu çalışmanın amacı öğretmen adaylarının derslerde bir eğitsel sosyal ağ (Edmodo) kullanımına ilişkin görüşlerini belirlemektir. Çalışmada nitel araştırma desenlerinden durum çalışması kullanılmıştır ve veriler yarı yapılandırılmış görüşme yöntemi kullanılarak toplanmıştır. Araştırmanın çalışma grubu Türkiye'nin batısında bulunan bir üniversitenin eğitim fakültesinin bilgisayar ve öğretim teknolojileri eğitimi bölümünün üçüncü sınıfında öğrenim gören 27 öğretmen adayıdır. Katılımcılar amaçsal örnekleme yöntemlerinden ölçüt örnekleme yöntemine göre belirlenmiştir. Görüşmelerden elde edilen veriler içerik analizi yöntemiyle analiz edilip kodlanmıştır. Çalışma sonucunda öğretmen adaylarının iletişim sağlama, kullanım kolaylığı, kaynaklara ulaşım, ders takibi, öğrenme kolaylığı, bilgiye erişim, geribildirimin hızı, ödev yüklemede kolaylık, sorumluluk bilinci sağlaması açısından derslerde eğitsel sosyal ağ kullanımı hakkında olumlu görüşlerinin olduğu görülmüştür. Çalışmaya katılan öğretmen adayları arayüz ile ilgili sorunlar, internet problemi, amaç dışı kullanım, anında geri dönüt verilmemesi, ödev teslim sorunları ve dosya boyutu sorunu açılarından olumsuz görüşler belirtmişlerdir.
\end{abstract}

Anahtar Sözcükler: Web 2.0 Araçları, Eğitsel Sosyal Ağ, Öğretmen Adayı, Görüş.

\section{Opinions of pre-service teachers on the use of an educational social networks in lessons}

\begin{abstract}
The aim of this study is to determine the opinions of pre-service teachers on the use of an educational social network in lessons. Case study, one of the qualitative research designs, was used in the study and the data were collected using semi-structured interview method. The study group of the research are 27 pre-service teachers studying in the third year in the department of computer education and instructional technology from a faculty of education at a university located in the west of Turkey. Participants were determined according to the criterion sampling method, one of the purposive sampling methods. The data obtained from the interviews were analyzed and coded by the content analysis method. As a result of the study, it was seen that the pre-service teachers had positive opinions about the use of educational social network in their lessons in terms of communication, ease of use, access to resources, course follow-up, ease of learning, access to information, speed of feedback, ease of submitting homework, and sense of responsibility. However, the pre-service teachers who participated in the study stated negative opinions in terms of interface problems, internet problem, misuse, not giving immediate feedback, problems in submitting homework, and file size problem.
\end{abstract}

Keywords: Web 2.0 Tools, Educational Social Network, Pre-Service Teacher, Opinion.

\footnotetext{
${ }^{1}$ 27-29 Nisan 2017 tarihlerinde Çanakkale, Türkiye'de düzenlenmiş olan VII. Uluslararası Eğitimde Araştırmalar Kongresinde sunulan ve Özeti Kitabı s. 85 ’te yayımlanan “Eğitim fakültesi öğrencilerinin eğitimde sosyal ağ kullanımına ilişkin görüşleri” başlıklı sözlü bildirinin genişletilmiş halidir.
} 


\section{Giriş}

21. yüzyılın başları itibariyle sanayi toplumundan bilgi toplumuna geçişin hızlı bir şekilde artmasıyla birlikte bilişim teknolojilerinde yeni gelişmeler ve değişimler gözlenmiştir. Oluşan gelişim ve değişimler çalışma ortamlarını ve iletişim araçlarını etkilediği gibi sosyal yaşantımızı da etkilemektedir (Ajan \& Hartshorne, 2008). Yaşanan gelişmeler ve değişimler neticesinde yeni ve farklı olanaklar sunan ortamlar oluşmuş ve bu ortamlarda bireylerin rollerinde değişiklik gözlenmiştir. Oluşan bu ortamların ortaya çıkmasında ve yaygın kullanımında Web 2.0 olarak adlandırılan internet teknolojileri gelmektedir (Conole \& Culver, 2010). Web 2.0 araçları bilgi ve iletişim teknolojilerindeki hızlı değişim ve gelişmenin en büyük göstergesidir. Web 2.0 araçlarının ortaya çıkmasıyla beraber bireyler bulundukları ağ ortamında kendi görüşünü ifade edebildiği ortamların oluşması ve bu sayede bireylerin etkin bir rol almaya başladığı görülmüştür. Web 2.0 araçları, kullanıcıların paylaşım yapmalarına ve iş birliği içerisinde hareket etmelerine olanak sağlayan, içerisinde internet araçları ve uygulamalarını barındıran uygulamalar olarak tanımlanmaktadır (Arroyo, 2011). Web 2.0 teknolojisinin ortaya çıkması ve gelişmesiyle birlikte son zamanlarda en sık kullanılan terimlerden birisi olan sosyal ağ kavramı ortaya çıkmıştır. Sosyal ağların kullanımı, hayatın birçok noktasını etkilediği gibi eğitim-öğretim faaliyetlerinde de etkisini göstermiştir (Balasubramanian ve diğerleri, 2014; Çankaya ve diğerleri, 2014; Durak, ve diğerleri, 2017). Bireylerin birbirleri ile olan iletişimini sanal ağ ortamlarına taşıyan sosyal medya araçları eğitim sistemini de etkilemiş bunun neticesinde sosyal medya araçlarının eğitim aracı olarak kullanımını artmıştır (Dere ve diğerleri, 2016).

Sosyal ağ ortamları öğretmen ve öğrenci arasındaki etkileşimi artırma, hızlı ve kolay geri dönüt, kaynakların paylaşımı, zaman ve mekândan bağımsız işbirliği içerinde çalışma ve iletişim kurma imkanı sağlamaktadır (Al-Rahmi ve diğerleri, 2018; Balakrishnan ve diğerleri, 2015; Mao, 2014; McLoughlin \& Lee, 2008; Prestridge, 2019; Thongmak, 2013; Trust, 2017). Sosyal ağlar öğrenciyi aktif hale getiren, yaratıcı ve işbirlikli çalışmayı destekleyen yapısı ile öğrenmeyi kolay hale getirmenin yanı sıra esnek ve kolay kullanımı sayesinde sınıf ortamı dışında etkileşime de olanak sağlamaktadır (Sırakaya, 2014). Diğer taraftan sosyal ağ kullanımının öğrenci başarısını düşürdüğünü (Junco, 2012; Kirschner \& Karpinski, 2010), öğretmen ve öğrenci rollerinin karışması nedeniyle öğretmenin otoritesinin zayıf hale geldiğini (Warner \& Esposito, 2009), öğrenciyi takip etmenin güç hale geldiğini (Chugh \& Ruhi, 2018), motivasyonun devamlılı̆̆ının sağlanamadığı (Dinçer, 2017; Shapiro ve diğerleri, 2017) ve bireylerin arasındaki etkileşimin tam kurulamadığını (Muilenburg \& Berge, 2005) ortaya 
koyan sosyal ağ kullanımının olumsuz sonuçlarını belirten çalışmalar da mevcuttur. Bu nedenle öğrencilerin sosyal ağ kullanma amaçlarının farklı sonuçlar doğurabileceğini söylemek mümkündür.

Öğretimde sosyal ağların kullanımı ile ilgili yapılan çalışmalar sonucunda eğitsel sosyal ağ kullanımı kavramı geliştirilerek, sosyal ağ ortamlarının özelliklerine sahip ancak ifade edilen olumsuzlukları taşımayan sistemler geliştirilmiştir (Durak ve diğerleri, 2014). Bu sistemlerden biri olan Edmodo arayüz tasarımı açısından Facebook ile benzerlik göstermektedir (Edmodo, 2021; Sarrab ve diğerleri, 2016). Bu sayede Facebook kullanan öğretmen ve öğrenciler Edmodo sosyal öğrenme ortamını kolaylıkla kullanabilirler. Eğitsel sosyal ağ olan Edmodo 2008 yılında kurulmuş ve 2011 yılında Amerika Okul Kütüphaneleri Birliği (American Association of School Librarians) [AASL] tarafından öğrenme ve öğretim alanında en iyi 25 web sitesinden biri olarak seçilmiştir (AASL, 2011). Edmodo, öğretmenin ve öğrencilerin güvenli bir şekilde bilgi paylaşımı yapabildiği, öğretmenin anketler ve quizler oluşturabildiği, ödev verebildiği ve not takibi yapabildiği bir sosyal öğrenme platformudur. Edmodo sayesinde öğretmen öğrencileriyle sanal ortamda iletişime geçebilir, belirli gün ve saate göre ödevler verebilir, ödevleri kimin teslim ettiğini ve içeriğini görebilir aynı zamanda ödevi puanlayabilir, eksik veya hatalı olan yerler için geribildirimlerde bulanabilir (Balasubramanian ve diğerleri, 2014; Kongchan, 2012; McLean ve diğerleri, 2017). Edmodo ortamında öğretmenler kendi branşlarındaki veya diğer branşlardaki öğretmenlerle iletişime geçebilir bu sayede fikir alışverişinde bulunabilir. Edmodo’ya erişim dizüstü ve masaüstü bilgisayarlardan, Android ve IOS işletim sistemli mobil cihazlardan ücretsiz bir şekilde sağlanabilmektedir. Edmodo platformu reklam içermemektedir. Edmodo eğitsel amaçlar için hazırlanmış güvenilir sosyal ağlar içerisinde en iyi örneklerden biri olarak düşünülebilir (Porcel ve diğerleri, 2018; Weber, 2012). Edmodo eğitsel sosyal öğrenme ağ1, öğrencilere öğretmenleri gözetiminde güvenilir bir ortam sağlamaktadır.

Alanyazın incelendiğinde eğitsel sosyal ağ olarak Edmodo'nun kullanımı ile ilgili araştırmaların son yıllarda arttığı görülmüştür. Kazez ve Bahçeci (2016), derslerinde Edmodo kullanan eğitim fakültesi Bilgisayar ve Öğretim Teknolojileri Eğitimi [BÖTE] bölümü ikinci sınıf öğrencileriyle yaptığı çalışmada hızlı gerçekleşen geribildirimin derse olan ilgiyi artırdığ1 ve ödev hazırlama konusunda motive edici olduğu sonucuna ulaşmıştır. Trust (2017), öğretmenlerle gerçekleştirdiği çalışmasında matematik dersinde Edmodo platformunu kullanmalarının öğretim uygulamalarını geliştirmek için motivasyon kazandırdığı, uygulamalarda değişiklik yapılması gereken kısımlarda uygulamayı geliştirme adına kendini 
daha iyi hissettikleri, bu sayede öğrenci merkezli ve yenilikçi uygulamaları hayata geçirme konusunda olumlu ifadeler kullandıkları sonucuna varmıştır. Dere ve diğerleri (2016), ilköğretim öğrencilerinin Edmodo platformunun özellikleri ve derste kullanımı ile ilgili görüşlerini almak amacıyla gerçekleştirdikleri çalışmada, öğrencilerin Edmodo platformunu kullanmalarının öğrenme sürecini olumlu yönde etkilediği sonucuna ulaşmışlardır. Kurt (2017), eğitim fakültesi ilköğretim matematik öğretmenliği bölümü üçüncü sınıf öğrencileriyle gerçekleştirdiği çalışmada Edmodo'dan yararlanarak öğrencilere günlük tutma, zihin haritaları, haftalık quizler gibi etkinlikler yapmıştır. Sonuç olarak, öğrencilerin arkadaşları ve öğretmeniyle etkileşimini ön planda olacak şekilde tasarlanmış harmanlanmış öğretim etkinliklerine olanak sağlamanın yanında etkileşimli olmasıyla da yüz yüze yapılan etkinliklerle harmanlanmasının öğrenme sürecini destekleyici olduğu sonucuna varmıştır. Kuzgun ve Özdinç (2017), Edmodo platformunun orta seviyede bir kullanılabilirliğe sahip olduğunu ve Türkçe dil ve yönlendirme desteği yanında Türkçe yardım paneli özelliklerinin geliştirilmesinin gerekliliğini belirtmiş̧tir. Hamutoğlu ve Kıyıcı (2017), derslerinde Edmodo kullanan eğitim fakültesi birinci sınıf öğrencileriyle gerçekleştirdikleri çalışmada öğrencilerin Edmodo platformunun derse odaklanmayı arttırdığı, öğrenme sürecine katkı sağladığı, zamandan ve mekandan bağımsız olarak kaynaklara kolay ulaşım sağladığı şeklinde görüşleri olduğunu bulmuştur. McLean ve diğerleri (2017), velilerin Edmodo platformu kullanarak çocuklarının altı haftalık bir zaman dilimi içerisinde oynadıkları oyunlar ile ilgili düşüncelerini paylaşmaları için kullanmışlardır. Çalışma sonucunda çocukların oynadıkları oyun türlerinde farklı bakış açılarına sahip oldukları görülmüş̧ür. Aldemir ve diğerleri (2018), tasarlamış oldukları avatar ve rozet gibi oyun öğelerini Edmodo platformu içerisinde dahil ederek ve sohbet kanalları oluşturarak öğrencilerin birbirleriyle haberleşmelerini amaçlayarak öğrencilerin algılarını belirlemişlerdir. Günbaş \& Yıldız (2020) matematik öğretmen adayları ile gerçekleştirdiği çalışmada matematik öğretim programı dersinde Edmodo kullanımı hakkındaki görüşleri incelemiştir. Çalışmada öğretmen adayları Edmodo hakkında olumlu görüşler yanında olumsuz görüşler de belirtmişlerdir. Alanyazında incelenen çalışmalarda farklı seviyelerdeki öğrencilerin eğitsel sosyal ağ kullandıkları, eğitsel sosyal ağ kullanımının öğrencilerin ders başarılarını ve motivasyonlarını artırdığı, zamandan ve mekandan bağımsız öğrenmeyi sağlamanın yanında kaynaklara ulaşımın kolay ve hızlı olması nedeniyle öğrencilerin eğitsel sosyal ağ kullanımı hakkında olumlu görüşlerinin olduğu görülmüştür.

Alanyazın incelendiğinde derslerde sosyal ağ kullanımı ile ilgili görüşlere yer veren çalışmaların çok fazla olmadığı görülmüş ve öğretmen adaylarının derslerde eğitsel sosyal ağ 
kullanımına ilişkin görüşlerini belirlemek amacıyla bu çalışmanın yapılmasına karar verilmiştir. Derslerde eğitsel sosyal ağ kullanımının önemli ölçüde arttığ1 günümüzde, bu çalışmanın eğitsel sosyal ağ kullanımı konusunda öğretmen adaylarının bakış açısından olumlu ve olumsuz ortaya çıkan yönleri ayrıntılı olarak ortaya koymak açısından alanyazına katkı getireceği düşünülmektedir. Araştırmanın problemi “öğretmen adaylarının derslerde eğitsel sosyal ağ (Edmodo) kullanımına ilişkin görüşleri nasıldır?” şeklinde belirlenmiştir. Araştırma problemine yanıt bulmak için belirlenen alt problemler şu şekildedir:

1. Öğretmen adaylarının derslerde Web 2.0 araçlarını kullanma hakkındaki görüşleri nasildir?

2. Öğretmen adaylarının öğrenim gördükleri öğretim yarıyılından önce Edmodo’yu kullanma durumları nasıldır?

3. Öğretmen adaylarının Edmodo’yu kullanmadan önceki beklentileri ve Edmodo’yu kullandıktan sonraki görüşleri nasıldır?

4. Öğretmen adaylarının Edmodo’yu kullanmak için tercih ettikleri bilişim teknolojisi araçları ve bu araçları tercih etme nedenleri nelerdir?

5. Öğretmen adaylarının derslerde Edmodo kullanmanın olumlu ve olumsuz olduğunu düşündükleri yönler nelerdir ve Edmodo kullanırken gördükleri olumsuzlukların giderilmesine yönelik görüşleri nasıldır?

6. Öğretmen adaylarının dersler dışında kullandıkları sosyal ağ ortamları ile Edmodo’yu karşılaştırma açısından görüşleri nasıldır?

\section{Yöntem}

\section{Araştırma Modeli}

Çalışma nitel araştırma modellerinden durum çalışması modeline göre yürütülmüştür. Nitel araştırma, değişkenler bilinmediği durumlarda incelemeler sonucunda değişkenlerini tanımlandığı aynı zamanda araştırma sorularının cevaplarının bulunduğu en uygun ve en sık kullanılan yöntem olarak ifade edilmektedir (Creswell, 2007). Durum çalışmaları, yaşanan çeşitli deneyimler, olaylar ve durumların derinlemesine ve ayrıntılı bir şekilde anlaşılması için gerçekleştirilen araştırmalardır (Yıldırım \& Şimşek, 2011). Çalışmada öğretmen adaylarının derslerde eğitsel sosyal ağ kullanımına ilişkin görüşlerinin ayrıntılı olarak ortaya konması amaçlandığından durum çalışması modeli kullanılmıştır. Durum çalışması araştırmalarında odaklanılan konuya ilişkin deneyimleri, olayları ve durumları ortaya koyabilecek kişiler veri kaynağı olduğundan görüşme başlıca veri toplama yöntemi olarak belirtilmiştir. Zengin veriler 
toplanmasına olanak sağladığı ve esnek olduğu için nitel araştırmalarda yarı yapılandırılmış görüşme yöntemi tercih edilmektedir (Yıldırım \& Şimşek, 2011).

\section{Araştırmanın Çalışma Grubu}

Çalışma grubu Türkiye'nin batısında bulunan bir üniversitenin eğitim fakültesinde BÖTE bölümünün üçüncü sınıfında öğrenim gören ve derslerinde Edmodo eğitsel sosyal ağ ortamını kullanan 27 öğretmen adayından oluşmaktadır. Katılımcılar amaçsal örnekleme yöntemlerinden ölçüt örnekleme yöntemi ile belirlenmiştir. Ölçüt örnekleme yöntemdeki amaç, önceden belirlenmiş kıstası veya kıstasları karşılayan durumların üzerinde çalışılmasıdır. Kıstas ya da kıstaslar araştırmacı tarafından oluşturulabildiği gibi önceden hazırlanmış bir kıstas listesi de kullanılabilir (Yıldırım \& Şimşek, 2011). Örnekleme yöntemindeki ölçüt öğretmen adaylarının derslerinde Edmodo eğitsel sosyal ağ ortamını aktif olarak kullanıyor olmalarıdır. Katılımcıların demografik özellikleri Tablo 1'de verilmiştir.

\begin{tabular}{|c|c|c|c|c|}
\hline \multicolumn{5}{|c|}{$\begin{array}{l}\text { Tablo } 1 \\
\text { Katılımcıların Demografik Özellikleri }\end{array}$} \\
\hline \multirow{2}{*}{ Özellikler } & & \multicolumn{2}{|c|}{ Cinsiyet } & \multirow[b]{2}{*}{ Toplam } \\
\hline & & Kadın & Erkek & \\
\hline \multirow[t]{2}{*}{ Kişisel bilgisayara sahip olma durumu } & Evet & 9 & 16 & 25 \\
\hline & Hayır & - & 2 & 2 \\
\hline \multirow{2}{*}{ İnternet erişimine sahip olma durumu } & Evet & 6 & 14 & 20 \\
\hline & Hayır & 3 & 4 & 7 \\
\hline \multirow{3}{*}{ Sosyal ağları kullanma durumu } & Evet & 9 & 18 & 27 \\
\hline & Hayır & - & - & - \\
\hline & Toplam & 9 & 18 & 27 \\
\hline
\end{tabular}

\section{Verilerin Toplanması}

Çalışmada veriler yarı yapılandırılmış görüşme yöntemi ile toplanmıştır. Bu amaçla yarı yapılandırılmış görüşme formu kullanılmıştır. Yarı yapılandırılmış görüşme formunda amaç, özel bir konuda derinlemesine soru sorma ve soru açık değilse daha açıklayıcı hale getirmektir (Çepni, 2007). Görüşme formundaki sorular hazırlanırken ilgili alanyazında yer alan çalışmalar incelenmiştir. Görüşme soruları hazırlandıktan sonra BÖTE alanında uzman olan iki akademisyene incelemeleri için verilmiştir. Uzmanların yapmış oldukları öneriler doğrultusunda sorular ve görüşme formu son şeklini almıştır. Görüşme formunda, öğretmen adaylarının kişisel bilgisayarlarının olup olmadığı, ihtiyaç duyduklarında kullandıkları İnternet 
bağlantılarının bulunup bulunmadığı, sosyal ağları aktif olarak kullanıp kullanmadıkları şeklindeki soruların yanı sıra derslerde Edmodo’yu kullanma hakkındaki görüşlerini öğrenmek amacı ile sorulmuş sorulara yer verilmiştir. Görüşmeler esnasında Edmodo’yu kullanma ile ilgili öğretmen adaylarına yöneltilen sorular bulgular bölümünde ifade edilmiştir.

\section{Verilerin Analizi}

Görüşmelerden elde edilen veriler yazılı hale getirilmiş ve birinci araştırmacı tarafından içerik analizi uygulanarak incelenip kodlanmıştır. İçerik analizinin amacı toplanan verileri açıklayıcı hale getirebilecek kavramlara ve ilişsilere ulaşmaktır (Yıldırım \& Şimşek, 2011). Araştırmanın güvenirliği için yazılı hale getirilen verilerden rasgele seçilen dört katılımcıya ait olanlar, ikinci araştırmacı tarafından kodlanmıştır. Kodlayıcılar arasındaki uyuşum Miles ve Huberman (1994) tarafından belirtilen Güvenirlik = [Görüş birliği olan kodların sayısı / (Görüş birliği olan kodların sayısı + Görüş ayrılığı olan kodların sayısı)] x 100 formülü kullanılarak hesaplanmıştır. Kodlayıcılar arası uyuşum oranı $25 / 125 \times 100=\% 80$ olarak bulunmuştur. Miles ve Huberman (1994), iki farklı kodlayıcının uyuşumu için \%70 üzerindeki değerlerin kodlayıcılar arası güvenirlik için yeterli olduğu belirtmiştir Buna göre yapılan kodlamaların güvenilir olduğu söylenebilir.

\section{Bulgular ve Yorumlar}

Araştırmanın birinci alt problemi olan "öğretmen adaylarının derslerde Web 2.0 araçlarını kullanma hakkındaki görüşleri nasıldır?” sorusuna yanıt bulmak için katılımcılara "Derslerinizde Web 2.0 araçlarını kullanıyor musunuz? Kullandığınız araçların isimleri nelerdir?" soruları yöneltilmiştir. 21 katılımcı en az bir Web 2.0 aracını ismini belirtmiştir. Altı katılımcı ise herhangi bir Web 2.0 aracı ismi belirtmemiştir. Katılımcılar tarafından belirtilen Web 2.0 araç isimleri incelendiğinde, Edmodo (13 katılımc1), Kahoot (5 katılımc1), Socrative (3 kat1lımc1), PowToon (2 katılımc1), LearningApps (2 katılımc1), Emaze (2 katılımc1), Aurasma (HP Reveal) (2 katılımc1), Facebook (2 katılımc1), Padlet (1 katılımc1), Prezi (1 katılımc1), karekod (1 katılımc1), Quiver (1 katılımc1), AnswerGarden (1 katılımc1), Wikipedia (1 katılımc1), Word (1 katılımc1), Excel (1 katılımc1), Powerpoint (1 katılımcı) şeklindedir. Soruya verilen yanıtlarda en çok bahsi geçen Web 2.0 aracının Edmodo olması, öğretmen adaylarının Edmodo'yu bir Web 2.0 aracı olarak gördükleri şeklinde yorumlanabilir.

Araştırmanın ikinci alt problemi olan “öğretmen adaylarının öğrenim gördükleri öğretim yarıyılından önce Edmodo’yu kullanma durumları nasıldır?” sorusuna yanıt bulmak için 
katılımcılara " $\mathrm{Bu}$ öğretim yarıyılından önce Edmodo kullandınız mı? Kullandıysanız hangi ders/derslerde kullandınız?" sorusu yöneltilmiştir. Soruya katılımcıların verdikleri yanıtlar analiz edildiğinde, 27 katılımcının daha önce Edmodo'yu kullandığı, bunların 13'ünün birinci sınıfta, 14'ünün ise ikinci sınıfta kullandığg görülmüştür. Katılımcıların Edmodo'yu kullandıklarını belirttikleri ders isimleri Programlama Dilleri (21 katılımcı), Eğitimde Materyal Tasarımı ve Kullanımı (12 katılımcı), Uzaktan Eğitim (11 katılımcı), Öğretim Tasarımı (6 katılımc1), İnternet Tabanlı Programlama (5 katılımc1), Özel Öğretim Yöntemleri (4 katılımcı), Öğretim İlke ve Yöntemleri (4 katılımc1), Eğitimde Bilişim Teknolojileri (3 katılımcı), Html’ye Giriş (2 katılımcı), Çoklu Ortam (2 katılımcı), Çoklu Ortam Tasarımı ve Üretimi (2 katılımc1), Eğitimde Grafik ve Canlandırma (2 katılımc1), Bilimsel Araştırma Yöntemleri (2 katılımcı), Web Tasarımı (2 katılımc1), Veri Tabanı Yönetim Sistemleri (1 katılımc1), Bilgisayar Donanımı (1 katılımcı), Bilim Etiği (1 katılımcı) şeklindedir. Soruya verilen yanıtlara göre öğretmen adaylarının Edmodo'yu alan derslerinde, alan eğitimi derslerinde, eğitim derslerinde ve genel kültür derslerinde yaygın olarak kullandıkları şeklinde yorum yapılabilir.

Araştırmanın üçüncü alt problemi olan “öğretmen adaylarının Edmodo’yu kullanmadan önceki beklentileri ve Edmodo’yu kullandıktan sonraki görüşleri nasıldır?” sorusuna yanıt bulmak için katılımcılara “Edmodo'yu kullanmadan önceki beklentileriniz nelerdi? Edmodo'yu kullandıktan sonraki görüşleriniz nasıldır?” soruları yöneltilmiştir. Öğretmen adaylarının Edmodo'yu kullanmadan önceki beklentileri ile ilgili verdikleri yanıtların analizinden elde edilen bulgular Tablo 2'de gösterilmiştir.

\begin{tabular}{|c|c|c|}
\hline \multicolumn{3}{|c|}{$\begin{array}{l}\text { Tablo } 2 \\
\text { Edmodo Kullanmadan Önceki Beklentiler }\end{array}$} \\
\hline Kategori & Kodlar & Yanıt sayısı \\
\hline \multirow{3}{*}{ Olumsuz beklentiler } & Arayüz kullanımı & 5 \\
\hline & İletișim & 5 \\
\hline & Yeni deneyim & 1 \\
\hline \multirow{4}{*}{ Olumlu beklentiler } & İletişim & 9 \\
\hline & Sosyal medyaya benzerlik & 3 \\
\hline & Kullanışlilık & 3 \\
\hline & Beklenti yok & 5 \\
\hline
\end{tabular}

Tablo 2 incelendiğinde, beş katılımcının “arayüz kullanımı” ile ilgili, beş katılımcının “iletişim” ile ilgili, bir katılımcının “yeni deneyim” ile ilgili olumsuz olarak kodlanan beklentisi olduğu görülebilir. “Arayüz kullanımı” ile ilgili olumsuz beklenti ifade eden katılımcılar, "yeni 
program olduğu için menülere alışma konusunda endişem vardı" (Katılımc1 1) ve "ilk olarak biraz karışık gelmişti, arayüz olarak tasarımı" (Katılımcı 19) şeklinde açıklamalar yapmışlardır. "İletişim” ile ilgili olumsuz beklenti ifade eden katılımcılar "dönüt sorunları yaşayabileceğimi düşünüyordum” (Katılımc1 24) ve "İngilizce olması, anlayamıyorum” (Katılımcı 25) şeklinde yanıtlar vermiştir. "Yeni deneyim” olarak kodlanan olumsuz beklenti ifade eden katılımcı "yeni deneyim kazanacă̆ım için endişeleniyorum” (Katılımcı 17) şeklinde görüş ifade etmiştir. Tablo 2 incelendiğinde, dokuz katılımcının "iletişim” ile ilgili, üç katılımcının "sosyal medyaya benzerlik" ile ilgili, üç katılımcının "kullanışlılık" ile ilgili olumlu olarak kodlanan beklentisi olduğu görülebilir. "İletişim” ile ilgili olumlu beklenti ifade eden katılımcılar "aynı platformda arkadaşlarımla derslerle ilgili daha iyi iletişime geçmek ve paylaşımlar yapmak”(Katılımc1 15) ve “ders döneminde arkadaşlarım ve öğretmenimle gerekli iletişimi sağlaması" (Katılımı 7) şeklinde açıklama yapmışlardır. "Sosyal medyaya benzerlik" olarak kodlanan olumlu beklenti ifade eden katılımcılar "sosyal medya sitelerine benzediği için yabancılık çekmedim" (Katılımc1 19) şeklinde, "kullanışlılık" ile ilgili olumlu olarak kodlanan beklenti ifade eden katılımcılar "kolay alışılabilir bir platform" (Katılımc1 5) şeklinde görüşler ifade etmişlerdir. Öğretmen adaylarının Edmodo’yu kullandıktan sonra görüşlerinin nasıl değiştiği sorusuna verdikleri yanıtlardan elde edilen bulgular Tablo 3 'te gösterilmiştir.

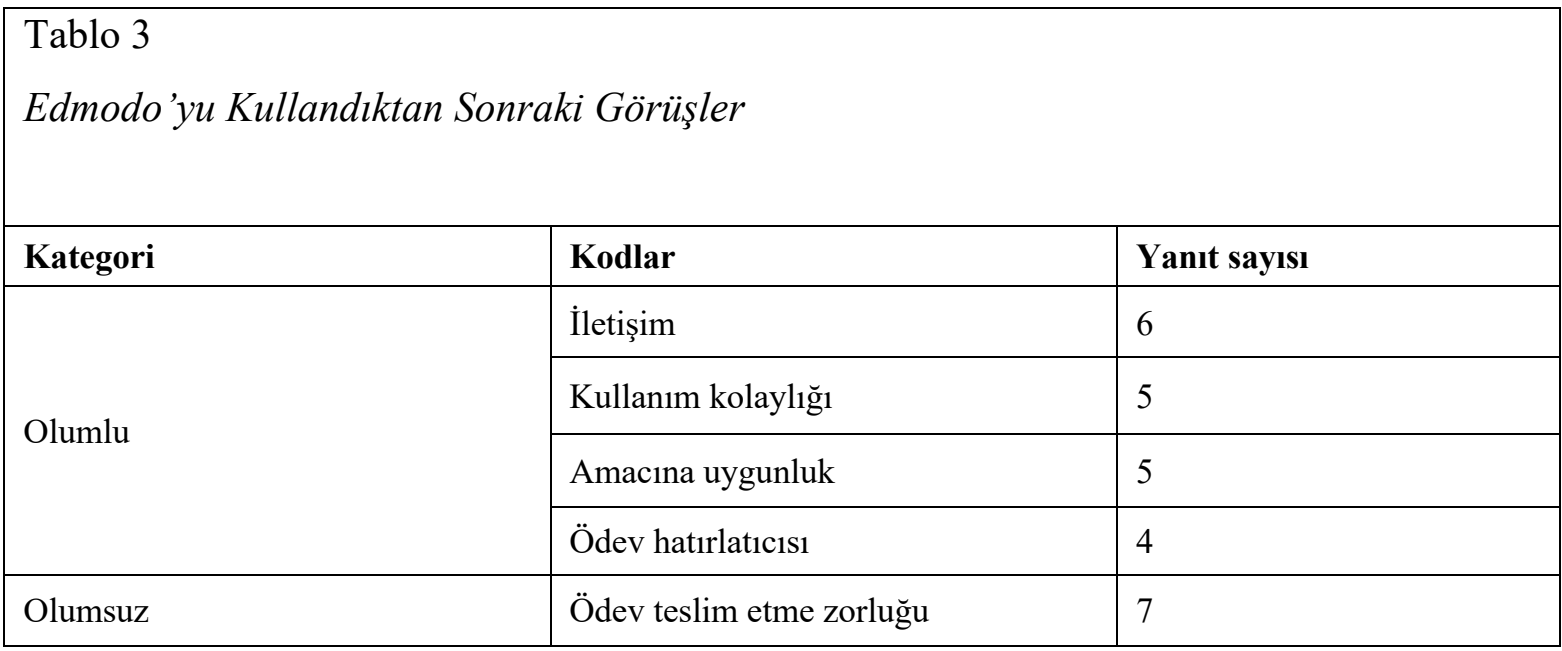

Tablo 3 incelendiğinde, katılımcıların Edmodo'yu kullandıktan sonraki görüşlerinin olumlu (20 katılımc1) ve olumsuz (7 katılımcı) olarak kategorisinde olduğu görülebilir. Edmodo'yu kullandıktan sonraki görüşleri olumlu kategorisinde olan katılımcılardan yanıtları "kullanım kolaylığı" olarak kodlananlar "kullanmaya alıştım rahat ve kolay şekilde 
kullanıyorum” (Katılımc1 20), "kullanımı çok kolay” (Katılımc1 2) ve "gayet rahat ve kullanışlı" (Katılımcı 25) şeklinde yanıtlar vermişlerdir. "İletişim” olarak kodlanan katılımcılar "bilgi ve fikir iletişimi bakımından kolaylık sağllyor" (Katılımcı 5), "Edmodo beklentimi karşıladl. İstediğim zaman iletişim kurabiliyorum” (Katılımc1 7) ve "öğretmenlerimin herhangi bir durumda mesajlarını, bilgi paylaşımını öğrenebiliyorum” (Katılımcı 10) şeklinde yanıt vermişlerdir. Yanıtları "amacına uygunluk" olarak kodlanan katılımcılar "amacına uygun” (Katılımc1 13) ve "amacına uygun etkili bir ortammış" (Katılımcı 12) şeklinde yorum yapmışlardır. Olumlu yanıtları "ödev hatırlatıcısı" olarak kodlanan katılımcılar "daha çok aktif kullanıyoruz ve beklediğim kadar yararlı. En azından ödevlerimizi hatırlamamıza yardımcı oluyor" (Katılımc1 9) ve "dersler ve ödevleri rahat takip edebiliyorum” (Katılımc1 25) şeklinde yanıtlar vermiştir. Görüşleri olumsuz kategorisindeki katılımcıların yanıtları “ödev teslim etme zorluğu” olarak kodlanmıştır ve bu katılımcılar “ödev teslim edemiyorum çünkü bazen yüklenmiyor" (Kat1lımc1 4) ve "ödevimi teslim ederken bazen sisteme yüklemiyor” (Katılımc1 1) şeklinde görüşler ifade etmişlerdir.

Araştırmanın dördüncü alt problemi olan “öğretmen adaylarının Edmodo’yu kullanmak için tercih ettikleri bilişim teknolojisi araçları ve bu araçları tercih etme nedenleri nelerdir?" sorusuna yanıt bulmak için katılımcılara 'Edmodo'yu kullanmak için tercih ettiğiniz bilişim teknolojisi araçları nelerdir? Bu araçları tercih etme nedeniniz nedir?” soruları yöneltilmiştir. Yanıtlar incelendiğinde Edmodo'yu kullanmak için 21 katılımcının telefonu tercih ettiğini, 16 katılımcının bilgisayarı tercih ettiğini ve 10 katılımcının her iki aracı da tercih ettiğini belirttiği görülmüştür. Edmodo'yu kullanmak için tercih edilen araçların tercih edilme nedenleri Tablo 4'de gösterilmiştir. 


Tablo 4
\begin{tabular}{|l|l|l|} 
Edmodo 'yu Kullanmak için Tercih Edilen Araçların Tercih Edilme Nedenleri \\
\hline Tercih edilen araçlar & Tercih edilme nedeni & Yanıt sayısı \\
\hline \multirow{4}{*}{ Telefon } & Erişim kolaylığı & 16 \\
\cline { 2 - 3 } & Neden yok & 5 \\
\hline \multirow{4}{*}{ Bilgisayar } & Dosya indirme veya yükleme & 4 \\
\cline { 2 - 3 } & Kullanım kolaylığı & 3 \\
\cline { 2 - 3 } & Teknik yetersizlik & 3 \\
\cline { 2 - 3 } & Neden yok & 6 \\
\hline
\end{tabular}

Tablo 4 incelendiğinde, 16 katılımcının Edmodo'yu kullanmak için telefonu tercih etme nedeni olarak "erişim kolaylığı” olarak kodlanan yanıtlar verdikleri görülebilir. Katılımcılar "telefon üzerinden daha rahat ulaşabiliyorum" (Katılımc1 7), "telefondan daha çok kullanıyorum çünkü bildirimler geliyor ve devamlı olarak takip edebiliyorum” (Kat1lımc1 14), "telefondan olması bildirimlerin anında olması açısından rahat oluyor" (Katılımcı 17), "telefon çünkü bilgisayar sürekli yanımda değil”" (Katılımc1 24), "telefon üzerinden çünkü telefon elimizin altında ve sürekli aktif bir şekilde kullanabiliyorum” (Katılımc1 22) ve “telefondan daha çoğunlukla çünkü sürekli açık olduğundan daha kolay” (Katılımc1 27) şeklinde yanıtlar vermişlerdir. Tablo 4 incelendiğinde, Edmodo'yu kullanmak için bilgisayarı tercih etme nedeni olarak dört katılımcının "dosya indirme veya yükleme”, üç katılımcının "kullanım kolaylığı”, üç katılımcının “teknik yetersizlik” olarak kodlanan yanıtlar verdikleri görülebilir. Yanıtları “dosya indirme veya yükleme” olarak kodlanan katılımc1lar “ödev teslim ya da bir yükleme yapacağım zaman bilgisayart tercih ediyorum” (Katılımc1 19), "ödevleri yapmak için bilgisayardan kullanıyorum” (Katılımc1 26), şeklinde yanıtlar vermişlerdir. Yanıtları "kullanım kolaylı̆̆ı" olarak kodlanan katılımcılar "bilgisayar üzerinden genelde. Kullanımı daha kolay” (Katılımc1 8), "bilgisayar üzerinden daha kolayıma geliyor” (Kat1lımc1 12), "bilgisayar üzerinden kullanmayı tercih ediyorum. Kullanımı daha rahat oluyor" (Katılımcı 23) şeklinde görüşler belirtmiştir. Yanıtları "teknik yetersizlik olarak" kodlanan katılımcılar "bilgisayar üzerinden kullanmayı tercih ediyorum. Telefonum olmadiğı için" (Katılımc1 1), "bilgisayar üzerinden çünkü telefonumun marka modeli kötü” (Katılımc1 16) ve "bilgisayardan kullanmayı tercih ediyorum. Telefondan bazı sekmelere ulaşamıyorum" (Katılımcı 10) şeklinde yanıtlar vermişlerdir. Edmodo'yu kullanmak için telefon ve 
bilgisayarın ikisini tercih ettiğinin belirten katılımcılar "duruma göre de ğişiyor. Hangisi yakınımdaysa onu kullanıyorum” (Katılımc1 4), "her ikisinden de kullanıyorum. Dosya indirmem gerekirse PC'den, ufak bir şey ise telefondan" (Kat1lımc1 6), "her ikisinden de kullanıyorum. Yapılan her şeyi ödevleri, sinavları anlık görebilmek için telefondan kullanıyorum” (Katılımc1 9), "ikisinden de kullanmayı tercih ediyorum daha çok telefonumdan kullanıyorum gelen bildirimler anında" (Katılımc1 18), "her ikisinden de kullanıyorum. Telefondan bildirimleri görüp anında okuma firsatım oluyor” (Katılımc1 25) şeklinde yanıtlar vermişlerdir.

Araştırmanın beşinci alt problemi olan "öğretmen adaylarının derslerde Edmodo kullanmanın olumlu ve olumsuz olduğunu düşündükleri yönler nelerdir ve Edmodo kullanırken gördükleri olumsuzlukların giderilmesine yönelik görüşleri nasıldır?” sorusuna yanıt bulmak için katılımcılara "Derslerinizde Edmodo kullanmanın olumlu ve olumsuz olduğunu düşündüğünüz yönler (iletişim ve kaynak paylaşma, öğrenme süreci, dönüt alma, ödev yükleme açısından) nelerdir? Edmodo kullanırken gördüğünüz olumsuzlukları gidermek için önerileriniz nelerdir?” soruları yöneltilmiştir. Katılımcıların Edmodo kullanımı hakkındaki görüşlerinin analizinden elde edilen bulgular Tablo 5'te gösterilmiştir. 


\begin{tabular}{|c|c|c|c|}
\hline \multicolumn{4}{|c|}{$\begin{array}{l}\text { Tablo } 5 \\
\text { Edmodo Kullanımı Hakkındaki Görüşler }\end{array}$} \\
\hline & Kategori & Kodlar & $\begin{array}{l}\text { Yanit } \\
\text { Sayısı }\end{array}$ \\
\hline \multirow{10}{*}{ Olumlu görüşler } & \multirow{3}{*}{$\begin{array}{l}\text { İletişim ve kaynak } \\
\text { paylaşımı }\end{array}$} & İletişim sağlama & 12 \\
\hline & & Kullanım kolaylığı & 9 \\
\hline & & Kaynaklara ulaşım & 6 \\
\hline & \multirow{3}{*}{ Öğrenme süreci } & Bilgiye erişim & 9 \\
\hline & & Ders takibi & 11 \\
\hline & & Öğrenme kolaylığı & 7 \\
\hline & \multirow{2}{*}{ Dönüt } & Geribildirim hızı & 13 \\
\hline & & İletişim sağlama & 14 \\
\hline & \multirow{2}{*}{ Ödev yükleme } & Kolaylık & 13 \\
\hline & & Sorumluluk & 11 \\
\hline \multirow{7}{*}{ Olumsuz görüşler } & \multirow{2}{*}{$\begin{array}{l}\text { İletişim ve kaynak } \\
\text { paylaşımı }\end{array}$} & Arayüz ile ilgili sorunlar & 12 \\
\hline & & İnternet problemi & 5 \\
\hline & Öğrenme süreci & Amaç dışı iletişim & 9 \\
\hline & Dönüt & $\begin{array}{l}\text { Anında geri dönüt } \\
\text { verilmemesi }\end{array}$ & 10 \\
\hline & \multirow{3}{*}{ Ödev yükleme } & Ödev teslim sorunları & 9 \\
\hline & & Dosya boyutu sorunu & 6 \\
\hline & & Ödevlerin görülmemesi & 4 \\
\hline
\end{tabular}

Tablo 5 incelendiğinde, 12 katılımcının "iletişim ve kaynak paylaşımı” kategorisinde “iletişim sağlama” olarak kodlanan olumlu görüşler belirttiği görülebilir. Bu katılımcıların görüşleri “mesajlara anında cevap verebilme olasılı̆̆ var. Not eksiğini belirttiğiniz zaman arkadaşlarda varsa paylaşabiliyorlar" (Katılımc1 8), "her an telefona girip bakabiliyorum. İstediğim öğretmene ve ögrrenci arkadaşıma ulaşabiliyorum” (Katılımc1 17), “istediğimizde ulaşma, hocayla iletişim”" (Katılımcı 24) şeklindedir. Dokuz katılımcının yanıtları "iletişim ve kaynak paylaşımı" kategorinde "kullanım kolaylığı" olarak kodlanmıştır. Bu katılımcılar "ödevlerden haberdar olma yönünden iyi. Kullanışı da basit” (Kat1lımc1 9), "eğitim için kullanılması kolay paylaşım imkanı sunması" (Katılımc1 14), "kolaylıkla dosya alışverişi yapabiliyor ve arkadaşlarımızın paylaşımlarına yorumlar yapabiliyoruz” (Katılımcı 23) 
şeklinde yanıtlar vermiştir. Altı katılımcının görüşleri "iletişim ve kaynak paylaşımı” kategorisinde "kaynaklara ulaşım” olarak kodlanmıştır. Bu katılımcılar "bence gayet çok güzel, tüm içeriklere o dersle ilgili olan örneklere bilgilere kolayca ulaşabiliyoruz” (Kat1lımc1 1), “duyuruları ana kaynaktan ögrenebiliyoruz” (Kat1lımc1 5), “bence gayet iyi bir özellik herkes ders ile ilgili materyallere rahatlıkla ulaşabiliyor" (Katılımcı 23) şeklinde görüşler ifade etmişlerdir. Yanıtları "öğrenme süreci” kategorisinde "bilgiye erişim”" olarak olumlu kodlanan katılımcıların sayısının dokuz olduğu Tablo 5'te yer almaktadır. Bu katılımcılar "bilgiye kolay erişim sağlıyor" (Katılımc1 4), "tüm bilgilere buradan ulaşabildiğimiz için ders konularında bir eksiklik yaşamıyorum" (Kat1lımc1 6), "notlara ve ders takibine daha kolay ulaşım" (Katılımc1 16) şeklinde yanıtlar vermişlerdir. 11 katılımcının yanıtları "öğrenme süreci”" kategorisinde "ders takibi” olarak kodlanmıştır. Bu katılımcılar "derslerimi takip ediyorum. Düzenli olarak mail ve bildirim geliyor" (Kat1lımc1 3), "sunumlarl sık sık takip edip tekrar etme firsatım oluyor" (Katılımcı 25) ş̧eklinde görüş belirtmişlerdir. Yedi katılımcının yanıtları “öğrenme süreci” kategorisinde "öğrenme kolaylığı” şeklinde kodlanmıştır. Bu katılımcılar "hazır bulunuşluk düzeyini artırıyor ve daha kolay ve hızlı öğreniyorum” (Katılımc1 15), "ögrrenmeyi pratikleştiriyor” (Katılımc1 12) şeklinde yanıtlar vermişlerdir. "Dönüt" kategorisinde "geribildirim hızı" olarak olumlu kodlanan yanıtların sayısının 13 olduğu Tablo 5'te görülebilir. Bu katılımcılar "verilen dönütler zamanındadır” (Katılımc1 14), "anında dönüt veriliyor” (Katılımc1 16), "bazen anında dönüt veriliyor" (Katılımc1 18), "zamanında ve tam anlaşılır dönütler alıyorum” (Katılımcı 24) şeklinde yanıtlar vermişlerdir. 14 katılımcının yanıtları "dönüt" kategorisinde "iletişim sağlama" olarak kodlanmıştır. Bu katılımcıları yanıtlarına örnekler "dönütler sayesinde bilmediğim konular aydınlanıyor" (Katılımc1 15), “dönütte öğrencinin eksikliklerini gidermesi açısından olumlu oluyor" (Katılımcı 23) şeklindedir. 13 katılımcı "ödev yükleme” kategorisinde "kolaylık" olarak kodlanan olumlu görüşler belirtmiştir. Bu katılımcılar “yüklenmesi basit ve kolay" (Katılımcı 9), "zaman kaybı değil. Masraftan kurtarıcı kağıt, kalem, proje hazırlarken kullanacă̆ımız materyal rahatça ödevi sanal ortamda hazırla, yükle ve teslim et” (Katılımc1 17), "teslim etme konusunda kolaylık sağlıyor" (Katılımcı 20) şseklinde görüşler ifade etmişlerdir. 11 katılımcı "ödev yükleme" kategorisinde "sorumluluk" olarak kodlanan olumlu görüşler belirtmiştir. bu katılımc1lar" ödevleri kendimizin yüklemesi daha önemli, sorumluluk bilinci kazandırır" (Katılımc1 5), “ödev yükleme öğrenciye sorumluluk bilinci katıyor” (Katılımc1 7), "herkes kendi ödevinden sorumlu” (Katılımc1 13) şeklinde yanıtlar vermiştir. 
Tablo 5 incelendiğinde, 12 katılımcının "iletişim ve kaynak paylaşımı” kategorisinde "arayüz ile ilgili sorunlar" olarak kodlanan olumsuz görüşler belirttiği görülebilir. Bu katılımcıların görüşleri “görünüş geliştirilebilir. Farklı özellikler katılabilir” (Katılımcı 7), "bildirim geldiğinde mail üzerinden geliyor. Direkt ekranda açılmıyor” (Kat1lımc1 17), "profil fotoğrafi güncellemede sıkıntılar yaşanabiliyor” (Katılımc1 27) şeklindedir. Beş katılımcının yanıtları "iletişim ve kaynak paylaşımı" kategorisinde "İnternet problemi” olarak olumsuz olarak kodlanmıştır. Bu katılımcılar "internetiniz yoksa sıkıntı” (Katılımcı 15), "internet sıkıntısı olduğu zaman etkin kullanılamıyor" (Katılımc1 20), "internet erişim olmadığı yerlerde sıkıntı doğurabilir” (Katılımcı 22) şeklinde görüşler belirtmiştir. Dokuz katılımcının yanıtları “öğrenme süreci” kategorisinde "amaç dışı iletişim” olarak kodlanmıştır. Bu katılımcılar "bilgisayar veya telefon üzerinden giriş yapıldiğ için bir süre sonra internette başka yerlere girmeye başlıyoruz ve zaman kaybı oluyor" (Katılımc1 8), "mesaj yorum yazmada fazla gereksiz şeyler olduğunu düşünüyorum” (Kat1lımc1 19) şeklinde yanıtlar vermişlerdir. 10 katılımcının yanıtları "dönüt" kategorisinde "anında geri dönüt verilmemesi olarak" kodlanmıştır. Bu katılımcılar "geri dönüt bazen çok uzun zaman sonra gerçekleşiyor" (Kat1lımc1 7), “anında dönütümü alamıyorum” (Kat1lımc1 15), "bazen ise çok uzun sürede geri dönüt veriliyor" (Katılımcı 18) şeklinde görüşler belirtmişlerdir. Dokuz katılımcının yanıtları “ödev yükleme” kategorisinde "ödev teslim sorunları” olarak kodlanmıştır. Bu katılımcılar “bazen yükleme sorunları oluşuyor” (Katılımcı 4), “yüklenirken yükleme sorunu yaşanması" (Katılımc1 14), “dosyanın eksiksiz şekilde karşı tarafa ulaştığııı göremediğimizden bazen sıkıntı çıkıyor. Dosya açılmıyor vs.” (Katılımcı 20) şeklinde yanıtlar vermişlerdir. Altı katılımcının yanıtları "ödev yükleme" kategorisinde "dosya boyutu sorunu" olarak kodlanmıştır. Bu katılımcıların yanıtları "sınırlı boyut sıkıntısı" (Katılımcı 8), "dosya boyutu sınırı” (Katılımcı 11), “dosyaları yüklerken belli bir büyüklüğü geçmemesi” (Katılımc1 14) şeklindedir. dört katılımcının görüşleri “ödev yükleme” kategorisinde “ödevlerinin görülmemesi” olarak kodlanmıştır. Bu katılımcılar “diğer öğrencilerin ödevlerini de onların izniyle görmemiz mümkün olsaydı daha güzel olurdu” (Katılımc1 3), “ödev herkese açıksa başkalarının da senin çalışmalarından haksız yere faydalanması” (Katılımcı 19) şeklinde görüşler ifade etmişlerdir.

Araştırmanın beşinci alt problemi için katılımcılara yöneltilen "Edmodo kullanırken gördüğünüz olumsuzlukları gidermek için önerileriniz nelerdir?” sorusuna verilen yanıtların analizinden elde edilen bulgular Tablo 6' da gösterilmiştir. 


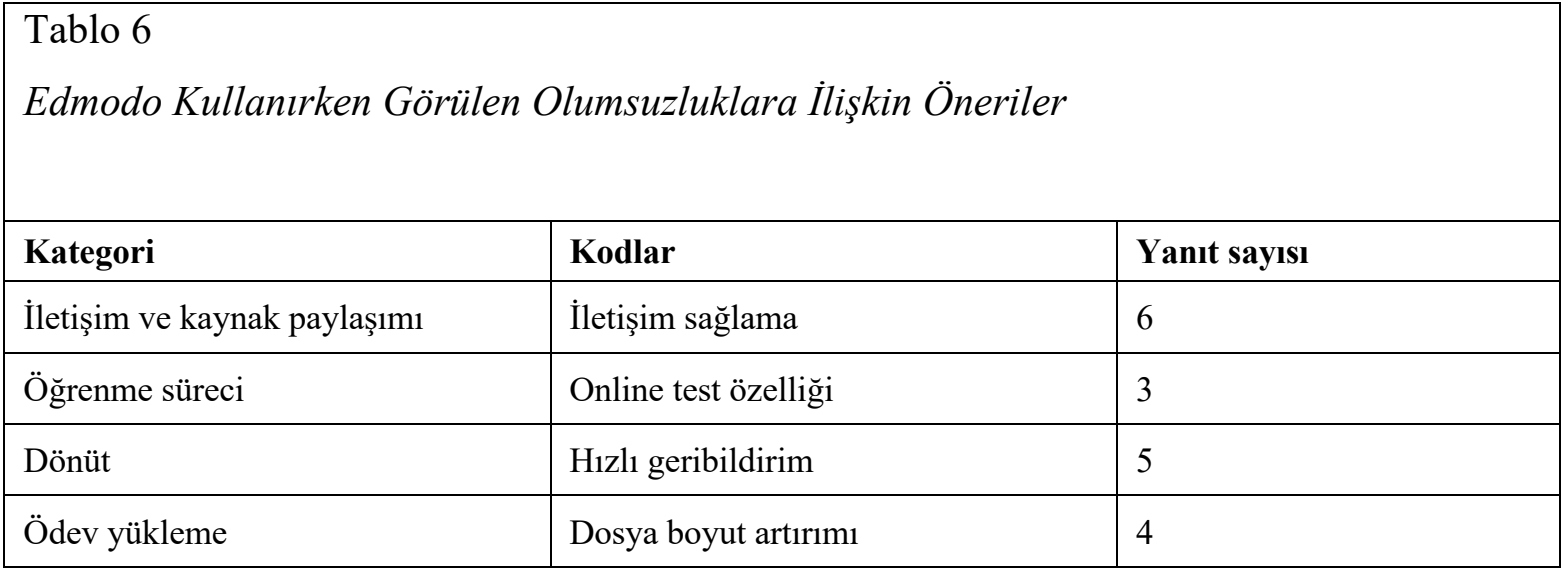

Tablo 6 incelendiğinde, altı katılımcının "iletişim ve kaynak paylaşımı” kategorisinde “iletişim sağlama” olarak kodlanan öneriler belirttiği görülebilir. Bu katılımcıların önerileri “online çevrimiçi kısmı olabilir. Hocalarımızla daha rahat iletişim için” (Katılımc1 10), "sms bildirimi eklenebilir" (Katılımcı 13), "sohbet panosu ve ögretmenimizin çevrimiçi olanları görebilmesi” (Katılımc1 23) şeklindedir. Üç katılımcı “öğrenme süreci” kategorisinde "online test özelliğgi” olarak kodlanan görüşler ifade etmişlerdir. Bu katılımcıların önerileri "daha çok uygulama ve test konabilir" (Katılımcı 5), "testler, klsa bilgi yarışmaları eklenebilir" (Katılımc1 10), "quiz yapmak” (Katılımc1 26) şeklindedir. Beş katılımcı "dönüt" kategorisinde "hızlı geribildirim" olarak kodlanan önerilerde bulunmuştur. Bu katılımcıların önerileri “online mesaj kutusu yapllabilir” (Kat1lımc1 10), "görülüp görülmeyen kişilere tekrar mesajları atılabilir (WhatsApp mavi tik gibi)” (Katılımc1 11), “yorum tekniklerini geliştirmek için örnek olarak emoji kullanılması” (Katılımcı 19) şeklindedir. Üç katılımcının önerisi “ödev yükleme” kategorisinde “dosya boyut artırımı” olarak kodlanmıştır. Bu katılımcılar "dosya kapasitesi artırılabilir” (Katılımc1 3), “dosya yüklemesi yaparken daha hızlı olmalı ve 100 MB'dan daha büyük dosyalarda atılabilmeli” (Kat1lımc1 6) şeklide görüşler ifade etmişlerdir.

Araştırmanın altıncı alt problemi olan "Öğretmen adaylarının dersler dışında kullandıkları sosyal ağ ortamları ile Edmodo’yu karşılaştırma açısından görüşleri nasıldır?” sorusuna yanıt bulmak için katılımcılara "Dersler dışında kullandığınız sosyal ağ ortamları (Facebook, Instagram, Twitter, WhatsApp, vb.) ile Edmodo’yu karşılaştır mısınız?” sorusu yöneltilmiştir. Katılımcıların bu soruya verdikleri yanıtların analizinden elde edilen bulgular Tablo 7'de gösterilmiştir. 


\begin{tabular}{|c|c|c|}
\hline \multicolumn{3}{|c|}{$\begin{array}{l}\text { Tablo } 7 \\
\text { Sosyal Ă̆ Ortamları ile Edmodo'nun Karşılaştırılmasına İlişkin Görüşler }\end{array}$} \\
\hline & Kodlar & Yanit sayısı \\
\hline \multirow{3}{*}{ Olumlu görüşler } & Öğrenme süreci & 14 \\
\hline & Kullanım kolaylığı & 7 \\
\hline & İletişim & 5 \\
\hline Olumsuz görüşler & İletişim & 10 \\
\hline
\end{tabular}

Tablo 7 incelendiğinde 14 katılımcının “öğrenme süreci” olarak kodlanan olumlu görüş ifade ettikleri görülebilir. Bu katılımcılar "çok fark yok. Birisi eğitim ă̆ırlıklı” (Katılımc1 5), "Edmodo eğitim için yapılmış ve amacının dışına çıkmayan site" (Katılımc1 13), "Edmodo'da sohbet dışında kullanımı çok iyi ve kolay. Facebook'a benziyor fakat Facebook'ta ödev verme gibi özellikler yok” (Katılımcı 23), şeklinde görüşler ifade etmişlerdir. Yedi katılımcı "kullanım kolaylığı” olarak kodlanan olumlu görüşler ifade etmiştir. Bu katılımcılar "Facebook daha dikkat dağıtıcı ama Edmodo sadece ders, proje odaklı olduğu için oraya odaklanmak daha kolay” (Katılımc1 17), "kullanımı çok basit hatta birçok platformdan daha sade” (Katılımcı 24), "kullanımı kolay, iletişsim kurma imkanları eğitim açısından yararlı çünkü kısıtlama var” (Katılımc1 26) şeklinde görüler ifade etmiştir. Beş katılımcının görüşleri "iletişim” olarak kodlanmıştır. Bu katılımcılar “ders grubuna kaydolan öğrencilerin birbirleriyle iletişim kurmaları gayet kolay oluyor. Ders grubunun yöneticisiyle de iletişime geçmek basit”" (Katılımc1 1), "diğerleri ile aynı. Hızlı iletişim kurmamızı sağlıyor” (Katılımcı 4) şeklinde yanıtlar vermişlerdir. Tablo 7 incelendiğinde 10 katılımcının "iletişim” olarak kodlanan olumsuz görüş ifade ettikleri görülebilir. Bu katılımcılar "Edmodo da iletişim sıklığı daha klsitll. Çevrimiçi bir ortam yok" (Katılımc1 10), "Facebook mesela görüntülü konuşabilme firsatı vardır. Yada çok kolay bir şekilde mesajlaşma ve aktif durumunun görülmesi. Edmodo’ya da görüntülü konuşma ve e-öğrenme üzerinden sınıfa çevrimiçi ders anlatımı olabilir”" (Kat1lımc1 22), "iletişim kurma imkanı pek yok. Ödevden ödeve, nottan nota gibi kolay. Herkes bireysel bu iyi bir şey. Ancak görüntülü ders imkanı olsa iyi olurdu” (Katılımcı 25) şeklinde görüşler ifade etmişlerdir. 


\section{Tartışma, Sonuç ve Öneriler}

Bu çalışmada Türkiye'nin batısında bulunan bir üniversitenin eğitim fakültesinin BÖTE bölümünün üçüncü sınıfında öğrenim gören ve derslerinde Edmodo eğitsel sosyal ağ ortamını kullanmakta olan 27 öğretmen adayının görüşleri alınmıştır. Nitel araştırma desenlerinden durum çalışması desenine göre yürütülen çalışmada veri toplama yöntemi olarak yarıyapılandırılmış görüşme kullanılmıştır. Görüşmelerde katılımcılara ilk olarak Web 2.0 araçlarını kullanma durumları ile ilgili bir soru sorulmuştur. Katılımcılara daha sonra derslerinde Edmodo’yu kullanma durumları, Edmodo'yu kullanmadan önceki beklentileri ve kullandıktan sonraki görüşleri, Edmodo’yu kullanmak için tercih ettikleri bilişim teknolojisi araçları ve bu araçları tercih etme nedenleri, Edmodo kullanmanın olumlu ve olumsuz olduğunu düşündükleri yönler, Edmodo kullanırken gördükleri olumsuzlukların giderilmesi, dersler dışında kullandıkları sosyal ağ ortamları ile Edmodo'nun karşılaştırılması konusunda sorular yöneltilmiştir.

Web 2.0 teknolojileri ile kullanımı yaygın hale gelen sosyal ağlar her yaştan bireyin katılımıyla yaygın olarak kullanılan ortamlar haline gelmiştir (Sırakaya, 2014). Esnek ve kullanıcıya kolaylık sağlamaları (Özmen ve diğerleri, 2012), işbirlikli öğrenme ortamlarının kullanılabilirliği (Gülbahar ve diğerleri, 2010), öğrenciyi aktif hale getirerek öğrenme sürecini kolay hale getirmeleri (Toğay ve diğerleri, 2013), öğretmen ve öğrencinin sınıf ortamı dışında da iletişim halinde olmalarına olanak sağlaması (Kılıçkaya, 2012) gibi avantajlar oluşturmasından dolayı sosyal ağların eğitimde kullanımı çok hızlı bir şekilde artmıştır. Bunun sonucu olarak Edmodo platformu gibi sosyal ağların tüm avantajlarını içerisinde barındıran ve sadece eğitim amaçlı kullanıma olanak sağlayan eğitsel sosyal ağ platformları ortaya çıkmıştır. Çalışmadan elde edilen bulgulara göre, katılımcıların büyük çoğunluğunun Web 2.0 aracı olarak Edmodo'dan bahsettikleri görülmüştür. Aynı zamanda katılımcıların Edmodo platformunu alan derslerinde, alan eğitimi derslerinde, eğitim derslerinde ve genel kültür derslerinde yaygın olarak kullandıkları sonucuna varılmıştır. Edmodo platformunun arayüzü sık kullanılan sosyal ağlardan biri olan Facebook'un arayüzü ile benzerlik göstermesi nedeniyle katılımcılara kolay geldiği ve bu sayede katılımcıların zorlanmadığı ve rahatlıkla kullandıkları sonucuna ulaşılmıştır.

Katılımcıların Edmodo kullanmanın olumlu olduğunu düşündükleri yönlerin, iletişim sağlama, kullanım kolaylığı, kaynaklara ulaşım, ders takibi, öğrenme kolaylığı, geribildirimin hızı, ödev yüklemede kolaylık, sorumluluk bilinci sağlama olduğu görülmüştür. Ulaşılan bu sonuç Hamutoğlu ve Kıyıcı (2017) tarafından yapılan çalışmanın sonucuyla benzerlik 
göstermektedir. Aynı zamanda yapılan çalışmada katılımcıların iletişim kolaylığı, zamandan tasarruf, kağıt ve kalem gibi proje hazırlarken kullanılacak olan materyallerden ziyade ödevini sanal ortamda hazırlayıp teslim etmenin maddi açıdan rahatlama sağlaması, katılımcıların ödevlerini sisteme kendilerinin yüklemesinin bireyde sorumluluk bilincini kazandırması, Edmodo'nun sınıf içerisindeki etkileşimi, öğrenme sürecine katkısı, geribildirimleri, ders ile ilgili kaynakların Edmodo üzerinden paylaşılması ve ödev/projelerin Edmodo'ya yüklenmesi ile ilgili katılımcı görüşleri neticesinde öğretmen adayları olumlu görüşler ifade etmişlerdir. Dersin kaynaklarına ulaşım ve ödevleri Edmodo üzerinden teslim etmeleri zaman tasarrufu yapmalarına olanak sağlamıştır. $\mathrm{Bu}$ sonuçlar alanyazındaki sonuçlarla ile benzerlik göstermektedir (Günbaş \& Y1ldız, 2020; Kılıçkaya, 2012; Sırakaya, 2014). Öğretmen adaylarının dersin öğretmeni ile iletişim kurma amacıyla Edmodo'yu derste kullanmasının faydalı olduğu, öğretmen öğrenci etkileşimini arttırdığı yönünde sonuçlara ulaşılmıştır. Bu sonuç alanyazında yer alan çalışmaların sonuçlarıyla benzerlik göstermektedir (Balasubramanian ve diğerleri, 2014; Günbaş \& Yıldız, 2020; Kongchan, 2012; Sanders, 2012; Sırakaya, 2014). Öğretmen adaylarının ödev teslim sürecinde Edmodo'yu kullanmaları zamandan tasarruf sağladığı gibi verilen geribildirimler sayesinde ödevlerinde bilinmeyen konuların aydınlanması ve eksikliklerin giderilmesi açısından olumlu görüşler ifade etmişlerdir. Bu durum öğretmen adaylarının Edmodo'nun ödev araçlarını beğendiği sonucuna ulaşan Çankaya ve diğerlerinin (2014) çalışmasında ulaşılan sonuçlarla tutarlılık göstermektedir. Ayrıca Edmodo platformuna ödevleri yüklemenin daha sonra istenilen zamanda tekrardan ödevlere dönmeyi ve yeniden görmeyi kolaylaştırdığı bu sayede de öğrencinin kendi öğrenmesinin sorumluluğunu almasını sağladığı sonucuna ulaşılmıştır. Öğretmen adaylarının kendi öğrenmelerinin sorumluluğunu alması durumu Sanders'ın (2012) çalışmasındaki sonuçla benzerdir.

Katılımcıların Edmodo kullanmanın olumsuz olduğunu düşündükleri yönlerinin, arayüz ile ilgili sorunlar, internet problemi, amaç dışı iletişim, anında geri dönüt verilmemesi, ödev teslim sorunları, dosya boyutu sorunu ve ödevlerinin görülememesi şeklinde olduğu görülmüştür. Edmodo platformu ile ilgili yapılan çalışmalarda platformun dilinin İngilizce olmasının (Günbaş \& Yıldız, 2020; Kazez \& Bahçeci, 2016; Kuzgun \& Özdinç, 2017) ve internet erişim sorununun (Baştuğ ve diğerleri, 2016) önemli problemler olduğu rapor edilmiş̧ir. Alanyazındaki çalı̧̧malarda rapor edilen bu problemlerle bu çalışma elde edilen sonuçlar benzerlik göstermektedir. Katılımcılar ayrıca bilgisayar veya telefon üzerinden Edmodo platformuna giriş yapıldığında bir süre internette başka sitelere girilmeye başlandığı 
bunun sonucu olarak amaç dışı kullanıma ortam hazırladığı, ödev tesliminde dosyanın eksiksiz bir şekilde karşı tarafa ulaşıp ulaşmama durumunun kontrolünün sağlanamaması, belirli bir dosya büyüklüğü üzerinde dosya gönderimine izin vermemesi, ödev yükleme alanında ödevini yükleyen katılımcıların bilgisinin ve ilgili dokümanın görülememesinin olumsuz olduğu şeklinde görüşler ifade etmişlerdir. Edmodo kullanımında karşılaşılan problemleri giderilmesine yönelik çalışmalar yapılması gerektiği önerisi yapılabilir.

Öğretmen adaylarının Edmodo platformunu geliştirmeye yönelik, sms bildirimi eklenmesi, sohbet paneli oluşturulması, öğretmenin çevrimiçi olanları görebilmesi, mesajların görülüp görülmeme durumuna göre tekrar mesaj gönderilmesi ve bunun kontrolü için WhatsApp platformundaki mavi tik işaretlemesine benzer yapının oluşturulması, yorum teknikleri geliştirilmesi için yorumlara emoji eklenebilmesi, dosya yükleme kapasitesinin hız ve boyutunun artırılması, görüntülü konuşma olanağı sağlanması, platformun çevrimiçi ders işlemek için uygun hale getirilmesi şeklinde öneriler içeren görüşler ifade etmişlerdir. Öğretmen adaylarının belirttikleri önerilerin uygunluğu konusunda çalışmalar yapılabilir.

Sonuç olarak, çalışmanın katılımcısı olan öğretmen adaylarının görüşlerine göre Edmodo platformunun her ders kapsamında kullanılabilir olduğu, iletişim, kullanım kolaylığı, kaynaklara ulaşım, ders takibi, öğrenme kolaylı̆̆ı, bilgiye erişim, geribildirimin hızı, ödev yüklemede kolaylık sağlaması açılarından olumlu yönlere sahip olduğu belirtilebilir. Fakat Edmodo platformunun, arayüz ile ilgili sorunlar, internet problemi, amaç dışı kullanım, anında geri dönüt verilmemesi, ödev tesliminde yaşanan sorunlar, dosya boyutu sorunu ve ödevlerin görülememesi açılarından olumsuz yönleri olduğu ve görülen sorunların giderilerek Edmodo platformunun kullanımı yaygınlaştırılması gerektiği söylenebilir.

Bu çalı̧̧ma eğitim fakültesi BÖTE bölümü üçüncü sınıfta öğrenim gören 27 öğretmen adayı ile gerçekleş̧irilmiştir. Farklı bir çalışmada başka bölümlerde öğrenim görmekte olan öğretmen adaylarıyla çalışma tekrarlanabilir. Bu çalışmada elde edilen sonuçlardan yola çıkılarak daha büyük örneklemlerde çalışmak amacıyla bir ölçek geliştirme çalışması yapılabilir. Çalışma küçük çalışma grubu ile yürütülerek sonuca varılmıştır. Böylece daha büyük çalışma gruplarıyla aynı çalışma yürütülerek katılımcılardan nitel veriler dışında nicel veriler toplanabilir. Katılımcıların Edmodo kullanımlarının gözlem yoluyla incelendiği bir çalışma yapılması da önerilebilir. 


\section{Kaynaklar}

Ajan, H., \& Hartshorne, R. (2008). Investigating faculty decisions to adopt web 2.0 technologies: Theory and empirical tests. Internet and Higher Education, 11(2), 71-80. https://doi.org/10.1016/j.iheduc.2008.05.002

Al-Rahmi, W. M., Alias, N., Othman, M. S., Marin, V. I., \& Tur, G. (2018). A model of factors affecting learning performance through the use of social media in Malaysian higher education. Computers and Education, 121, 59-72. https://doi.org/10.1016/j.compedu.2018.02.010

Aldemir, T., Çelik, B. \& Kaplan, G. (2018). A qualitative investigation of student perceptions of game elements in a gamified course. Computers in Human Behavior, 78, 235-254. https://doi.org/10.1016/j.chb.2017.10.001

Amerika Okul Kütüphaneleri Birliği (American Association of School Librarians) [AASL] (2011). 2011 top 25 websites for teaching and learning. https://www.ala.org/aasl/sites/ala.org.aasl/files/content/standards/websites/docs/BW_ Bookmark2011.pdf

Arroyo, C. G. (2011). On-line social networks: Innovative ways towards the boost of collaborative language learning. https://conference.pixelonline.net/conferences/ICT4LL2011/common/download/Paper_pdf/CLL16-428-FPGonzalez-ICT4LL2011.pdf

Balakrishnan, V., Liew, T. K. ve Pourgholaminejad, S. (2015). Fun learning with Edooware A social media enabled tool. Computers \& Education, 80, 39-47. https://doi.org/10.1016/j.compedu.2014.08.008

Balasubramanian, K., Jaykumar, V., \& Fukey, L. N. (2014). A study on student preference towards the use of Edmodo as a learning platform to create responsible learning environment. Procedia-Social and Behavioral Sciences, 144, 416-422. https://doi.org/10.1016/j.sbspro.2014.07.311

Baştuğ, İ., Solmaz, İ., Kaledibi, F. \& İşbulan, O. (2016, Ekim). 5. ve 6. sınıf öğrencilerinin programlama eğitiminde Edmodo kullanımına yönelik görüşlerinin değerlendirilmesi. 4th International Instructional Technologies \& Teacher Education Symposium: ReDiscover Learning with Digital Learners içinde (s. 76-84). Firat Üniversitesi, Elazı ̆. https://ittes.org.tr/dosyalar/files/IttesArsivi/2016/fulltext-proceeding-ittes2016.pdf

Chugh, R., \& Ruhi, U. (2018). Social media in higher education: A literature review of Facebook. Education and Information Technologies, 23(2), 605-616. https://doi.org/10.1007/s10639-017-9621-2

Conole, G., \& Culver, J. (2010). The design of cloudworks: Applying social networking practice to foster the exchange of learning and teaching ideas and designs. Computers and Education, 54(3), 679-692. https://doi.org/10.1016/j.compedu.2009.09.013 
Creswell, J. W. (2007). Qualitative inquiry \& research design: Choosing among five approaches. Sage.

Çankaya, S., Durak, G., \& Yünkül, E. (2014). Using educational social networking sites in higher education: Edmodo through the lenses of undergraduate students. European Journal of Educational Technology, 1(1), 3-23. https://ejetech.org/index.php/EJETECH/article/view/9/4

Çepni, S. (2007). Araştırma ve proje çalışmalarına giriş (Genişletilmiş 3. Baskı). Celepler Matbaacilik.

Dere, E., Avcı Yücel, U., \& Yalçınalp, S. (2016). İlköğretim öğrencilerinin eğitsel bir çevrimiçi sosyal öğrenme ortamı olan Edmodo’ya ilişkin görüşleri. İlköğretim Online, 15(3), 804819. https://doi.org/10.17051/io.2016.49794

Dinçer, S. (2017). Ortaokul öğrencilerinin bilgisayar okuryazarlık düzeylerinin belirlenmesi ve ölçme-değerlendirme araçlarının yapısı. Illköğretim Online, 16(3), 1329-1349. https://doi.org/10.17051/ilkonline.2017.330261

Durak, G., Çankaya, S., \& Yünkül, E. (2014). Eğitimde eğitsel sosyal ağ sitelerinin kullanımı: Edmodo örneği. Dumlupınar Üniversitesi Sosyal Bilimler Dergisi, 41, 309-316. https://dergipark.org.tr/en/download/article-file/55994

Durak, G., Çankaya, S., Yünkül, E., \& Öztürk, G. (2017). The effects of a social learning network on students' performances and attitudes. European Journal of Education Studies, 3(3), 312-333. https://doi.org/10.5281/zenodo.292951

Edmodo (2021). Edmodo homepage. https://new.edmodo.com/?go2url=/home

Gülbahar, Y., Kalelioğlu, F., \& Madran, O. (2010, Aralık). Sosyal ağların eğitim amaçlı kullanımı. XV. Türkiye'de İnternet Konferanst. İstanbul, Türkiye. http://inettr.org.tr/inetconf15/inet-tr10-ozet.html

Günbaş, N. \& Yıldız, H. (2020). Matematik öğretim programı dersinde Edmodo sosyal paylaşım platformunun kullanımı: Öğretmen adaylarının görüşleri. Bayburt Eğitim Fakültesi Dergisi, 15(29), 109-129. https://doi.org/10.35675/befdergi.478788

Hamutoğlu, N. B., \& Kıyıcı, M. (2017). Bir eğitsel sosyal ă̆ olarak Edmodo'nun yükseköğretimde kullanımı hakkındaki öğrenci görüşlerinin incelenmesi. Trakya Üniversitesi Eğitim Fakültesi Dergisi, 7(2), 322-343. https://doi.org/10.24315/trkefd.290573

Junco, R. (2012). The relationship between frequency of Facebook use, participation in Facebook activities, and student engagement. Computers \& Education, 58(1), 162-171. https://doi.org/10.1016/j.compedu.2011.08.004

Kazez, H., \& Bahçeci, F. (2016). BÖTE bölümü öğretmen adaylarının Edmodo kullanımına dair görüşlerinin incelenmesi. Eğitim ve Öğretim Araştırmaları Dergisi, 5(1), 9-20. http://www.jret.org/FileUpload/ks281142/File/02a.habibe_kazez.pdf

K1lıçkaya, F. (2012). Edmodo: Make your language classroom a community. AATSEEL Newsletter, 55(1), 7-10. http://www.aatseel.org/100111/pdf/aatseelfeb12nl.pdf 
Kirschner, P. A., \& Karpinski, A. C. (2010). Facebook ${ }^{\circledR}$ and academic performance. Computers in human behavior, 26(6), 1237-1245. https://doi.org/10.1016/j.chb.2010.03.024

Kongchan, C. (2012, November). How a non-digital-native teacher makes use of Edmodo. 5th International Conference ICT for Language Learning. Florence, Italy. https://conference.pixelonline.net/conferences/ICT4LL2012/common/download/Paper_pdf/90-IBT18-FPKongchan-ICT2012.pdf

Kurt, Ç. S. (2017). Bir harmanlanmış öğrenme deneyimi. İlköğretim Online, 16(2), 860-886. https://doi.org/10.17051/ilkonline.2017.304740

Kuzgun, H., \& Özdinç, F. (2017). Eğitsel sosyal ağ ortamı Edmodo'nun kullanılabilirliğinin incelenmesi. Kuramsal Eğitimbilim Dergisi, 10(2), 274-297. https://doi.org/10.5578/keg.54103

Mao, J. (2014). Social media for learning: A mixed methods study on high school students' technology affordances and perspectives. Computers in Human Behavior, 33, 213-223. https://doi.org/10.1016/j.chb.2014.01.002

McLoughlin, C. E., \& Lee, M. J. W. (2008) Future learning landscapes: transforming pedagogy through social software. Innovate: Journal of Online Education, 4(5), 539. https://nsuworks.nova.edu/innovate/vol4/iss5/1

McLean, K., Edwards, S., \& Morris, H. (2017). Community playgroup social media and parental learning about young children's play. Computers \& Education, 115, 201-210. https://doi.org/10.1016/j.compedu.2017.08.004

Muilenburg, L. Y., \& Berge, Z. L. (2005). Student barriers to online learning: A factor analytic study. Distance Education, 26(1), 29-48. https://doi.org/10.1080/01587910500081269

Özmen, F., Aküzüm, C., \& Sünkür, M. (2012). Sosyal ağ sitelerinin eğitsel ortamlardaki işlevselliği. Education $\quad$ Sciences, $\quad 7(2), \quad$ 496-506. https://dergipark.org.tr/tr/download/article-file/185434

Porcel, C., Ching López, A., Lefranc, G., Loia, V., \& Herrera Viedma, E. (2018). Sharing notes: An academic social network based on a personalized fuzzy linguistic recommender system. Engineering Applications of Artificial Intelligence, 75, 1-10. https://doi.org/10.1016/j.engappai.2018.07.007

Prestridge, S. (2019). Categorising teachers' use of social media for their professional learning: A self-generating professional learning paradigm. Computers \& Education, 129, $143-$ 158. https://doi.org/10.1016/j.compedu.2018.11.003

Sanders, K. S. (2012). An examination of the academic networking site Edmodo on student engagement and responsible learning (Yayımlanmamış doktora tezi). College of Education, University of South Carolina. 
Sarrab, M., Elbasir, M., \& Alnaeli, S. (2016). Towards a quality model of technical aspects for mobile learning services: An empirical investigation. Computers in Human Behavior, 55, 100-112. https://doi.org/10.1016/j.chb.2015.09.003

Shapiro, H. B., Lee, C. H., Wyman Roth, N. E., Li, K., Çetinkaya-Rundel, M., \& Canelas, D. A. (2017). Understanding the massive open online course (MOOC) student experience: An examination of attitudes, motivations, and barriers. Computers \& Education, 110, 35-50. https://doi.org/10.1016/j.compedu.2017.03.003

Sırakaya, M. (2014). Öğretmen adaylarının Edmodo hakkındaki görüşleri. 8th International Computer \& Instructional Technologies Symposium. Edirne, Türkiye. https://dosyalar.trakya.edu.tr/egitim/docs/Kongreler/ICITS2014_TamMetin.pdf

Thongmak, M. (2013). Social network system in classroom: Antecedents of Edmodo adoption. Journal of E-Learning and Higher Education, 2013, 1-15. https://doi.org/10.5171/2013.657749

Trust, T. (2017). Motivation, empowerment, and innovation: Teachers' beliefs about how participating in the Edmodo math subject community shapes teaching and learning. Journal of Research on Technology in Education, 49(1-2), 16-30. https://doi.org/10.1080/15391523.2017.1291317

Toğay, A., Akdur, T. E., Yetişken, İ. C., \& Bilici, A. (2013, Ocak). Eğitim süreçlerinde sosyal ağların kullanımı: Bir MYO deneyimi. XIV. Akademik Bilişim Konferansı. Antalya, Türkiye. https://ab.org.tr/ab13/bildiri/302.pdf

Warner, B., \& Esposito, J. (2009). What's not in the syllabus: Faculty transformation, role modeling and role conflict in immersion service-learning courses. International Journal of Teaching and Learning in Higher Education, 20(3), 510-517. https://files.eric.ed.gov/fulltext/EJ869335.pdf

Weber, A. (2012). Considerations for social network site SNS use in education. International Journal of Digital Information and Wireless Communications, 2(4), 306-321. https://citeseerx.ist.psu.edu/viewdoc/download?doi=10.1.1.845.8132\&rep=rep1\&type $=$ pdf

Yıldırım, A., \& Şimşek, H. (2011). Sosyal bilimlerde nitel araştırma yöntemleri. Seçkin Yayıncilik. 


\section{Yazarlar Hakkında}

\section{Çisem YAŞAR}

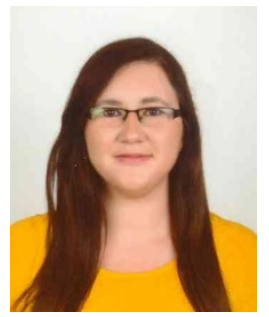

Gelişim Üniversitesi, İstanbul, Gelişim Meslek Yüksekokulu Bilgisayar Teknolojileri Bölümü'nde Öğr. Görevlisi olarak görev yapmaktadır. Yüksek lisansını 2019 yılında bilgisayar ve öğretim teknolojileri eğitimi alanında yapmıştır. Başlıca araştırma alanları teknoloji bağımlılığı, sosyal öğrenme ağları, bilgi güvenliği ve siber güvenlik teknolojileridir.

Tel (İş):

+902124227000

GSM:

+905452494469

Eposta:

cyasar@gelisim.edu.tr

\section{Gülcan ÖZTÜRK}

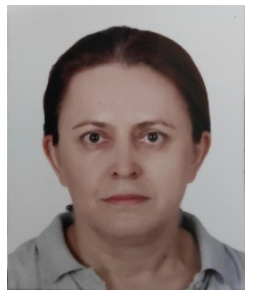

Balıkesir Üniversitesi, Balıkesir, Necatibey Eğitim Fakültesi Bilgisayar ve Öğretim Teknolojileri Eğitimi Bölümü'nde Dr. Öğr. Üyesi olarak görev yapmaktadır. Doktorasını 2013 yılında matematik eğitimi alanında tamamlamıştır. Başlıca araştırma alanları öğretmen eğitimi, öğretim ortamına teknoloji entegrasyonu, sosyal öğrenme ağları, dijital vatandaşlık, revize edilmiş Bloom taksonomisidir.

Tel (İs): $\quad$ +902662412762

GSM:

+905057194595

Eposta:

ozturkg@balikesir.edu.tr 